\title{
The Evaluation of Barringtonia asiatica on Indomethacin Induced Ulceration on Albino Rats
}

\section{Umaru $\mathrm{IJ}^{1,2 *}$ and Umaru $\mathrm{HA}^{3}$}

${ }^{1}$ Faculty of Resource Science and Technology, University of Malaysia Sarawak, Kuching, Kota Samarahan, Malaysia ${ }^{2}$ Department of Biochemistry, Federal University Wukari, Taraba, Nigeria

${ }^{3}$ Department of Biochemistry, Modibo Adama University of Technology, Yola, Adamawa, Nigeria

\begin{abstract}
Objective: The aim of this study was to evaluate the effect of Barringtonia asiatica hexane extract on animal induced ulceration

Materials and Methods: In this study indomethacin was administered to induce gastric ulcer. Rats were divided into eight groups: Healthy animals, untreated animals (acetic acid-induced), treatment group of $100 \mathrm{mg} / \mathrm{kg} /$ bwt, $200 \mathrm{mg} / \mathrm{kg} / \mathrm{bwt}, 300 \mathrm{mg} / \mathrm{kg} / \mathrm{bwt}, 400 \mathrm{mg} / \mathrm{kg} / \mathrm{bwt}$ and $500 \mathrm{mg} / \mathrm{kg} / \mathrm{bwt}$ and positive control group of Omeprazole $25 \mathrm{mg} / \mathrm{kg} / \mathrm{bwt}$ was measured through histopathology examination and ulceration observation. Haematological parameters were also evaluated before and after treatments to indicate the safety profile of various concentration of Barringtonia asiatica extract.

Results: The untreated animals developed more serious injuries (i.e., bigger and more severe ulcers) than the omeprazole control groups and extract treatment groups. The hexane crude extract of Barringtonia asiatica treatment with doses of $100 \mathrm{mg} / \mathrm{kg} / \mathrm{bwt}, 200 \mathrm{mg} / \mathrm{kg} / \mathrm{bwt}, 300 \mathrm{mg} / \mathrm{kg} / \mathrm{bwt}, 400 \mathrm{mg} / \mathrm{kg} / \mathrm{bwt}$ and $500 \mathrm{mg} / \mathrm{kg} / \mathrm{bwt}$ were effective to heal the ulcer as shown by reduction of ulcer size (up to $13.94 \%, 33.46 \%, 51.87 \%, 64.34 \%$ and $86.54 \%$ respectively) compared to the untreated animals. The Barringtonia asiatica extract was as effective as omeprazole $2 \mathrm{mg} / \mathrm{kg} / \mathrm{bwt}$ in alleviating ulcer severity as examined in histopathology result. There were no significant differences in haematological values. Hexane extract at doses of $100 \mathrm{mg} / \mathrm{kg} / \mathrm{bwt}, 200 \mathrm{mg} / \mathrm{kg} / \mathrm{bwt}, 300 \mathrm{mg} / \mathrm{kg} / \mathrm{bwt}, 400 \mathrm{mg} / \mathrm{kg} /$ bwt and $500 \mathrm{mg} / \mathrm{kg} / \mathrm{bwt}$ demonstrated healing activity on indomethacin-induced gastric ulcer, with a similar or more effect to that of omeprazole at dose of $25 \mathrm{mg} / \mathrm{kg} / \mathrm{bwt}$.
\end{abstract}

Conclusion: No adverse reaction was seen in all treatment groups, suggesting that Barringtonia asiatica hexane crude extract has a good safety profile in animal and ulcer induced.

Keywords: Barringtonia asiatica; Animal; Ulceration; Omeprazole; Indomethacin

\section{Introduction}

Peptic ulcers are injuries in the mucosal areas immersed in gastric acid and pepsin, where the areas are covered with mucin secreted from mucus cells. Ulceration occur when there is imbalance between offensive and defensive factors [1]. Such factors could range from natural causes (gastric cancer), infections (Helicobacter pylori), and lifestyle (drugs-non-steroidal anti-inflammatory drugs, alcohol, stress and cigarette smoking) $[2,3]$. Ulceration in the mucosa can be because of either breakdown of mucosa with the development of surface defects or failure of restitution of mucosal integrity resulting in retardation or failure of healing of the ulcers.

It could also result from imbalance between gastro protective activity and aggressive factors such as acid pepsin secretion, mucosal barrier, mucus secretion, blood flow, cellular regeneration, prostaglandins and epidermal growth factors [4]. It is one of the most common gastrointestinal disorders in clinical practice which is generally treated with modern medicines such as cimetidine and omeprazole. Considering potential side effects arising from these medicines, such as constipation, decreased bone mineral density and hematopoietic events due to higher aluminium concentration, novel medicines should be sought for as an alternative in treatment of internal diseases [5].

The medicinal plant of interest Barringtonia asiatica is a species of Barringtonia native to mangrove habitats on the tropical; it is a common plant in the Malaysian Mangroves and wetlands such as the Kuching wetlands Sarawak and Bako National Park. It is used as sausage food among the native of Sarawakian in the kampong as well as a medicinal plant, inhabitants of several West African countries, Nigeria and the Polynesian Islands use liquid from the crushed bark of Barringtonia asiatica to treat chest pains and heart troubles. The same plant is used in Papua New Guinea to treat stomach-aches [6].

In recent years, we have conducted many studies on the potential use of herbal extracts for treatment of different kinds of diseases, especially on Barringtonia asiatica extract for bacterial activity, phytochemical evaluation and antioxidant Properties, ulcer and diabetes treatment [6,7-10]. A bioactive fraction present in this plant extract has been proven to have antibacterial and antioxidant effect, such as pharmacological properties this would be beneficial for treatment and prevention of Helicobacter pylori induced peptic ulcer as well. Thus, this research work aimed at identifying the potential of Barringtonia asiatica as an ulcer healing agent fraction from the hexane extract. In this regards the extract was studied in indomethacin induced gastric ulceration.

*Corresponding author: Dr. Isaac John Umaru, Faculty of Resource Science and Technology, University of Malaysia Sarawak, Kuching, Kota Samarahan, Malaysia, Tel: +60 82-581 000; E-mail: umaruisaac@gmail.com

Received August 25, 2018; Accepted September 05, 2018; Published September 10,2018

Citation: Umaru IJ, Umaru HA (2018) The Evaluation of Barringtonia asiatica on Indomethacin Induced Ulceration on Albino Rats. J Mol Genet Med 12: 365 doi:10.4172/1747-0862.1000365

Copyright: $@ 2018$ Umaru IJ, et al. This is an open-access article distributed under the terms of the Creative Commons Attribution License, which permits unrestricted use, distribution, and reproduction in any medium, provided the original author and source are credited 
Citation: Umaru IJ, Umaru HA (2018) The Evaluation of Barringtonia asiatica on Indomethacin Induced Ulceration on Albino Rats. J Mol Genet Med 12: 365 doi:10.4172/1747-0862.1000365

Page 2 of 5

\section{Material and Methods}

\section{Chemicals}

Diagnostic kits for alanine aminotransferase (ALT), aspartate aminotransferase (AST), alkaline phosphatase (ALP) and bilirubin were purchased from Randox Laboratories Ltd, albumin from Sigma Diagnostic, United Kingdom, which contain bromocresol green. Omeprazole and Indomethacin (reference drug) was obtained from Medical Resource SDN BHD Kuching, Sarawak.

\section{Materials}

Barringtonia asiatica were collected in Kampong Sarawak Malaysia by the river bank and Meranak at Meranak river bank in KotaSamarahan Sarawak. Identification of the species was made by Prof Dr. Fasihuddin Bin Badruddin Ahmad and Prof Dr Zaini B Assim. The samples were air-dried, cut into pieces and ground prior to analysis. It was then deposited into the polymer laboratory at Department of Chemistry, Faculty of Resource Science and Technology, UNIMAS.

\section{Preparation of hexane extract}

The plant Barringtonia asiatica leaf were washed with distilled water to remove the soil and dust particles they were thoroughly air dried and powdered using laboratory grinder machine (FGR-350, Quest Scientific) extraction using hexane by placing $150 \mathrm{~g}$ of the powdered samples into an Erlenmeyer flask and hexane three times the weight of the extracts was added, the solution was covered and shaken at an interval of an hour and then allowed at room temperature to stand for 7 days, the mixture were then filtered using Whatman filter paper No. 4 and the solvent was evaporated using a rotary evaporator (Heidolph Laborato 400) under reduced pressure below 50EC. It was then stored under a frozen condition until required.

\section{Animals (Albino rats)}

Forty male albino rats weighing between (150-190 g) were obtained from the animal farm, University Malaysia Sarawak. They were put in cages at room temperature $\left(20-27^{\circ} \mathrm{C}\right)$ under $12 / 12$ night/dark. They were maintained on a standard animal pellets (vital feeds, Grands cereals and oil meal Jos) and water ad libitum.

\section{Experimental procedures}

The experiment was carried out according to the method by Umaru et al. [7]. The albino rats were randomly divided into eight groups, which are healthy animals $(n=5)$, this include normal group, negative and positive control group while five groups for extracts dosage, except the normal all the groups were induced with ulcer, the animals were starved from food 24 hours and water 2 hours before the commencement of the experiment.

Twelve hours before blood sampling, rats were fasted and placed in the metabolic cage (no food, water ad libitum). After fasting, blood samples were collected, and ulceration was induced with indomethacin. Three days after (day 1 of treatment), the animals were treated as follows;

\section{Group 1: Normal control (diet/water)}

Group 2: Rats (Induced ulcer indomethacin $25 \mathrm{mg} / \mathrm{kg} / \mathrm{bwt}+$ diet /water)

Group 3: Rats (Induced ulcer indomethacin $25 \mathrm{mg} / \mathrm{kg} / \mathrm{bwt}+$ diet/ water + Omeprazole)
Group 4: Rats (Induced ulcer indomethacin $25 \mathrm{mg} / \mathrm{kg} / \mathrm{bwt}+\operatorname{diet} /$ water $+100 \mathrm{mg} / \mathrm{kg} / \mathrm{bwt}$ extracts).

Group 5: Rats (Induced ulcer indomethacin $25 \mathrm{mg} / \mathrm{kg} / \mathrm{bwt}+$ diet / water $+200 \mathrm{mg} / \mathrm{kg} / \mathrm{bwt}$ extracts)

Group 6: Rats (Induced ulcer indomethacin $25 \mathrm{mg} / \mathrm{kg} / \mathrm{bwt}+$ diet / water $+300 \mathrm{mg} / \mathrm{kg} / \mathrm{bwt}$ extracts)

Group 7: Rats (Induced ulcer indomethacin $25 \mathrm{mg} / \mathrm{kg} / \mathrm{bwt}+$ diet / water $+400 \mathrm{mg} / \mathrm{kg} / \mathrm{bwt}$ extracts)

Group 8: Rats (Induced ulcer indomethacin $25 \mathrm{mg} / \mathrm{kg} / \mathrm{bwt}+$ diet / water $+500 \mathrm{mg} / \mathrm{kg} / \mathrm{bwt}$ extracts)

For twenty-one days. At the end of the experiment, rats were euthanized using pentobarbital injection. Pathology condition of gastric, ulcer area and haematological data were observed in this study.

\begin{tabular}{|c|c|c|c|c|c|}
\hline Group & $\mathbf{n}$ & $\begin{array}{c}\text { Treatment/ } \\
\text { Dose (mg/kg/ } \\
\text { bwt) }\end{array}$ & $\begin{array}{c}\text { Ulcer Indices } \\
\text { Area }\left(\mathbf{m m}^{\mathbf{2}} \mathbf{\text { before }}\right. \\
\text { Treatment }\end{array}$ & $\begin{array}{c}\text { Rats } \\
\text { Weights before } \\
\text { Treatment }\end{array}$ & $\begin{array}{c}\text { Protection } \\
\mathbf{( \% )}\end{array}$ \\
\hline Group 1 & 5 & - & - & - & - \\
\hline $\begin{array}{c}\text { Group 2 } \\
(- \text { ve) }\end{array}$ & 5 & 25 & $55.53 \pm 0.70$ & $149.56 \pm 7.55$ & $0 \%$ \\
\hline $\begin{array}{c}\text { Group 3 } \\
\text { (+ve) }\end{array}$ & 5 & 20 & $54.17 \pm 0.05^{\mathrm{a}}$ & $151.11 \pm 11.46$ & $0 \%$ \\
\hline Group 4 & 5 & 100 & $44.34 \pm 0.46^{\mathrm{a}}$ & $153.89 \pm 7.13$ & $0 \%$ \\
\hline Group 5 & 5 & 200 & $65.64 \pm 0.56^{\mathrm{a}}$ & $160.76 \pm 9.85^{\mathrm{c}}$ & $0 \%$ \\
\hline Group 6 & 5 & 300 & $55.55 \pm 0.34^{\mathrm{a}}$ & $155.42 \pm 7.97^{\mathrm{c}}$ & $0 \%$ \\
\hline Group 7 & 5 & 400 & $56.29 \pm 0.12^{\mathrm{a}}$ & $162.77 \pm 11.15^{\mathrm{c}}$ & $0 \%$ \\
\hline Group 8 & 5 & 500 & $54.45 \pm 0.31^{\mathrm{ab}}$ & $152.47 \pm 6.47^{\mathrm{c}}$ & $0 \%$ \\
\hline
\end{tabular}

Note: There was no ulcer developed in the health rats.

asignificantly $(p>0.05)$ decreased compared to negative control.

ab Significantly $(p>0.05)$ decreased compared to different extract concentration per group.

Significantly $(p>0.05)$ increased compared to negative control.

Table 1: Effect of hexane leaf extracts of Barringtonia asiatica on indomethacin induced ulcer (Ulcer area before treatment).

\begin{tabular}{|c|c|c|c|c|c|}
\hline Group & $\mathbf{n}$ & $\begin{array}{c}\text { Treatment/ } \\
\text { Dose (mg/kg/ } \\
\text { bwt) }\end{array}$ & $\begin{array}{l}\text { Ulcer } \\
\text { Indices } \\
\text { Area after } \\
\text { treatment } \\
\left(\mathrm{mm}^{2}\right)\end{array}$ & $\begin{array}{c}\text { Rats } \\
\text { Weights } \\
\text { after } \\
\text { treatment }\end{array}$ & $\begin{array}{l}\text { Protection } \\
(\%)\end{array}$ \\
\hline Group 1 & 5 & - & - & - & - \\
\hline $\begin{array}{c}\text { Group } 2 \\
(-\mathrm{ve})\end{array}$ & 5 & 25 & $55.87 \pm 0.80$ & $\begin{array}{c}151.65 \pm \\
8.49\end{array}$ & $0 \%$ \\
\hline $\begin{array}{c}\text { Group } 3 \\
(+v e)\end{array}$ & 5 & 20 & $0.56 \pm 0.03^{a}$ & $\begin{array}{c}154.05 \pm \\
10.47\end{array}$ & $92.80 \%$ \\
\hline Group 4 & 5 & 100 & $3.01 \pm 0.38^{a}$ & $\begin{array}{c}154.92 \pm \\
6.48\end{array}$ & $13.94 \%$ \\
\hline Group 5 & 5 & 200 & $1.93 \pm 0.67^{a}$ & $\begin{array}{c}161.89 \pm \\
10.87^{\circ}\end{array}$ & $33.46 \%$ \\
\hline Group 6 & 5 & 300 & $2.03 \pm 0.28^{a}$ & $\begin{array}{c}157.36 \pm \\
8.06^{c}\end{array}$ & $51.87 \%$ \\
\hline Group 7 & 5 & 400 & $1.45 \pm 0.43^{a}$ & $\begin{array}{c}161.89 \pm \\
12.03^{\mathrm{c}}\end{array}$ & $64.34 \%$ \\
\hline Group 8 & 5 & 500 & $1.01 \pm 0.23^{\mathrm{ab}}$ & $\begin{array}{c}154.37 \pm \\
7.40\end{array}$ & $86.54 \%$ \\
\hline \multicolumn{6}{|c|}{$\begin{array}{l}\text { Note: Values are Mean } \pm \text { SD }(n=5) \\
\text { aSignificantly }(p>0.05) \text { decreased compared to negative control. } \\
\text { abSignificantly }(p>0.05) \text { decreased compared to different extract concentration } \\
\text { per group. } \\
\text { 'Significantly }(p>0.05) \text { increased compared to negative control. }\end{array}$} \\
\hline
\end{tabular}

Table 2: Effect of hexane leaf extracts of Barringtonia asiatica on indomethacin induced ulcer. (Ulcer severity score). 
Citation: Umaru IJ, Umaru HA (2018) The Evaluation of Barringtonia asiatica on Indomethacin Induced Ulceration on Albino Rats. J Mol Genet Med 12: 365 doi:10.4172/1747-0862.1000365

Page 3 of 5

\begin{tabular}{|c|c|c|c|c|c|c|c|c|c|}
\hline \multirow{2}{*}{ Description } & \multirow{2}{*}{ Ulcer Group } & \multirow{2}{*}{ Normal Group } & \multirow{2}{*}{ Negative Group } & \multirow{2}{*}{ Positive Group } & \multicolumn{5}{|c|}{ Extract Treatment Group (mg/kg/bwt) } \\
\hline & & & & & 100 & 200 & 300 & 400 & 500 \\
\hline WBC $\left(\times 10^{6} / \mu \mathrm{L}\right)$ & $3 \pm 1.6$ & $8.487 \pm 1.66$ & $7.61 \pm 2.55$ & $7.5 \pm 0.58$ & $7.43 \pm 1.34$ & $7.41 \pm 0.32$ & $7.45 \pm 1.22$ & $.53 \pm 0.21$ & $7.58 \pm 0.08$ \\
\hline $\operatorname{RBC}\left(\times 10^{6} / \mu \mathrm{L}\right)$ & $7.12 \pm 0.21$ & $6.844 \pm 1.03$ & $7.33 \pm 0.77$ & $7.16 \pm 0.37$ & $7.07 \pm 0.33$ & $7.09 \pm 0.42$ & $7.11 \pm 0.01$ & $7.13 \pm 0.11$ & $7.16 \pm 0.08$ \\
\hline $\mathrm{HGB}(\mathrm{g} / \mathrm{dl})$ & $.08 \pm 1.2$ & $14.71 \pm 1.13$ & $16.01 \pm 0.93$ & $15.19 \pm 0.77$ & $15.07 \pm 1.03$ & $15.09 \pm 0.06$ & $15.11 \pm 0.12$ & $15.09 \pm 0.11$ & $15.16 \pm 1.02$ \\
\hline НСТ (\%) & $.14 \pm 4.52$ & $8.36 \pm 3.66$ & 26 & 3.01 & $39.78 \pm 2.37$ & $39.98 \pm 2.31$ & $40.1 \pm 1.56$ & $39.99 \pm 2.01$ & $40.3 \pm 1.88$ \\
\hline Platelets $\left(\times 10^{6} / \mathrm{K}\right.$ & $739.9 \pm 169.32$ & 214.1 & 46.3 & 49.01 & $748.8 \pm 0.23$ & $749.6 \pm 34.3$ & $749.5 \pm 44.7$ & $750.2 \pm 38.3$ & $750.3 \pm 56.7$ \\
\hline $\mathrm{MCV}(\mathrm{FI})$ & $34 \pm 2.15$ & $.43 \pm 2.76$ & $.87 \pm 1.12$ & $49.67 \pm 1.13$ & $50.35 \pm 1.23$ & $49.89 \pm 0.98$ & $50.44 \pm 1.02$ & $50.31 \pm 1.23$ & $51.02 \pm 1.45$ \\
\hline $\mathrm{MCH}(\mathrm{pg})$ & $.19 \pm 1.65$ & $17.93 \pm 0.14$ & $18.01 \pm 0.03$ & $17.97 \pm 0.49$ & $18.13 \pm 0.66$ & $18.15 \pm 0.54$ & $18.17 \pm 3.2$ & $18.17 \pm 5.21$ & $18.18 \pm 0.53$ \\
\hline $\mathrm{MCHC}(\mathrm{g} / \mathrm{DI})$ & $33.46 \pm 3.55$ & $33.45 \pm 1.22$ & $33.57 \pm 3.54$ & $33.01 \pm 08$ & $33.51 \pm 0.56$ & $33.57 \pm 0.66$ & $33.59 \pm 1.10$ & $33.60 \pm 2.12$ & $33.63 \pm 2.23$ \\
\hline RDW (\%) & $09.36 \pm 6.17$ & $10.34 \pm 0.52$ & $09.69 \pm 0.68$ & $08.78 \pm 0.24$ & $10.35 \pm 1.2$ & $10.33 \pm 1.09$ & $10.33 \pm 2.31$ & $09.76 \pm 4.5$ & $09.56 \pm 5.6$ \\
\hline РСТ (\%) & 1 & $263 \pm 0.12$ & $0.254 \pm 0.10$ & 0.254 & $0.310 \pm 0.04$ & $0.308 \pm 0.01$ & $0.287 \pm 0.05$ & $0.277 \pm 0.03$ & $0.275 \pm 0.06$ \\
\hline MPV (fL) & \pm 0.33 & $8 \pm 1.03$ & .46 & 0.16 & $3.45 \pm 0.29$ & $3.36 \pm 0.38$ & $3.33 \pm 0.46$ & $3.34 \pm 0.02$ & $3.32 \pm 0.12$ \\
\hline PDW (\%) & $14.15 \pm 0.06$ & 14.62 .0 .33 & $13.88 \pm 1.0$ & $14.2 \pm 0.173$ & $14.10 \pm 0.87$ & $14.08 \pm 0.73$ & $14.01 \pm 0.21$ & $13.56 \pm 0.19$ & $13.47 \pm 0.43$ \\
\hline
\end{tabular}

Table 3: Haematology before treatment.

\begin{tabular}{|c|c|c|c|c|c|c|c|c|c|}
\hline \multirow[t]{2}{*}{ Description } & \multirow[t]{2}{*}{ Ulcer Group } & \multirow[t]{2}{*}{ Normal Group } & \multirow[t]{2}{*}{ Negative Group } & \multirow[t]{2}{*}{ Positive Group } & \multicolumn{5}{|c|}{$\begin{array}{l}\text { Extract Treatment Group } \\
(\mathrm{mg} / \mathrm{kg} / \mathrm{bwt})\end{array}$} \\
\hline & & & & & 100 & 200 & 300 & 400 & 500 \\
\hline WBC $\left(\times 10^{6} / \mu \mathrm{L}\right)$ & $7.83 \pm 0.09$ & $8.83 \pm 1.34$ & $8.22 \pm 2.67$ & $7.92 \pm 3.76$ & $7.86 \pm 1.22$ & $7.87 \pm 0.98$ & $7.873 \pm 0.79$ & $7.93 \pm 0.31$ & $7.97 \pm 0.01$ \\
\hline $\operatorname{RBC}\left(\times 10^{6} / \mu \mathrm{L}\right)$ & $6.51 \pm 0.34$ & $6.89 \pm 0.43$ & $6.43 \pm 0.45$ & $7.12 \pm 0.68$ & $6.76 \pm 0.45$ & $6.79 \pm 1.03$ & $6.782 \pm 1.02$ & $6.88 \pm 0.02$ & $6.895 \pm 1.03$ \\
\hline HGB (g/dL) & $14.27 \pm 0.59$ & $14.89 \pm 0.75$ & $14.21 \pm 0.78$ & $14.15 \pm 0.87$ & $14.03 \pm 1.09$ & $14.06 \pm 2.01$ & $14.05 \pm 0.07$ & $14.073 \pm 0.12$ & $14.076 \pm 0.05$ \\
\hline HCT (\%) & $36.89 \pm 2.13$ & $38.18 \pm 1.89$ & $37.62 \pm 1.67$ & $38.64 \pm 3.01$ & $37.34 \pm 2.01$ & $37.47 \pm 0.09$ & $37.49 \pm 0.03$ & $38.01 \pm 0.04$ & $38.02 \pm 0.02$ \\
\hline Platelets $\left(\times 10^{6} / \mu \mathrm{L}\right)$ & $721.1 \pm 63.2 \mathrm{bdce}$ & $998.57 \pm 87.1$ & $1001.4 \pm 86.3 a$ & $739.78 \pm 105.3$ & $906.5 \pm 0.08 a$ & $913.8 \pm 44.1 \mathrm{a}$ & $914.7 \pm 56.2 a$ & $918.34 \pm 66.1 \mathrm{a}$ & $919.4 \pm 76.3 a$ \\
\hline MCV (fL) & $53.09 \pm 11.3$ & $49.63 \pm 1.78$ & $50.11 \pm 0.60$ & $48.88 \pm 1.45$ & $49.64 \pm 0.63$ & $50.12 \pm 0.22$ & $50.13 \pm 0.46$ & $50.71 \pm 0.03$ & $50.87 \pm 0.77$ \\
\hline $\mathrm{MCH}(\mathrm{pg})$ & $19.09 \pm 1.12 \mathrm{bf}$ & $16.88 \pm 0.66$ & $17.77 \pm 0.67$ & $17.67 \pm 0.89$ & $18.67 \pm 0.01$ & $18.59 \pm 1.23$ & $18.77 \pm 1.31$ & $18.79 \pm 0.01$ & $18.98 \pm 0.32$ \\
\hline $\mathrm{MCHC}(\mathrm{g} / \mathrm{dL})$ & $33.98 \pm 0.67$ & $33.15 \pm 2.01$ & $34.25 \pm 2.01$ & $31.65 \pm 2.31$ & $33.23 \pm 0.03$ & $33.32 \pm 0.45$ & $33.43 \pm 2.33$ & $33.39 \pm 0.67$ & $33.41 \pm 1.23$ \\
\hline RDW (\%) & $10.63 \pm 0.73$ & $10.14 \pm 0.42$ & $10.03 \pm 0.07$ & $11.43 \pm 1.77$ & $11.03 \pm 0.07$ & $11.12 \pm 0.07$ & $11.34 \pm 1.1$ & $11.29 \pm 1.03$ & $11.36 \pm 0.06$ \\
\hline PCT (\%) & $0.259 \pm 0.01 \mathrm{bde}$ & $0.503 \pm 0.06$ & $0.456 \pm 0.05$ & $0.411 \pm 0.08$ & $0.421 \pm 1.22$ & $0.422 \pm 0.01$ & $0.437 \pm 2.03$ & $0.447 \pm 0.08$ & $0.453 \pm 0.09$ \\
\hline MPV (fL) & $3.61 \pm 0.44$ & $2.99 \pm 0.36$ & $2.86 \pm 0.09$ & $3.72 \pm 0.30$ & $3.48 \pm 2.01$ & $3.51 \pm 0.67$ & $3.56 \pm 1.23$ & $3.53 \pm 0.67$ & $3.55 \pm 0.54$ \\
\hline PDW (\%) & $14.55 \pm 0.35$ & $13.77 \pm 0.88$ & $14.53 \pm 0.56$ & $14.05 \pm 2.01$ & $14.17 \pm 1.08$ & $14.17 \pm 0.04$ & $14.18 \pm 0.02$ & $14.17 \pm 1.03$ & $14.183 \pm 1.30$ \\
\hline
\end{tabular}

Note: (a) $p<0.05$ vs. ulcer producing group, (b) $p<0.05$ vs. Healthy animals, (c) $p<0.05$ vs. Untreated animals (d) $p<0.05 v s$. treatment group with hexane extract dose $100-500 \mathrm{mg} / \mathrm{kg} / \mathrm{bwt}$ (e) $p<0.05 \mathrm{vs}$. positive control group omeprazole at dose $25 \mathrm{mg} / \mathrm{kg} / \mathrm{bwt}$

Table 4: Haematology after treatment.

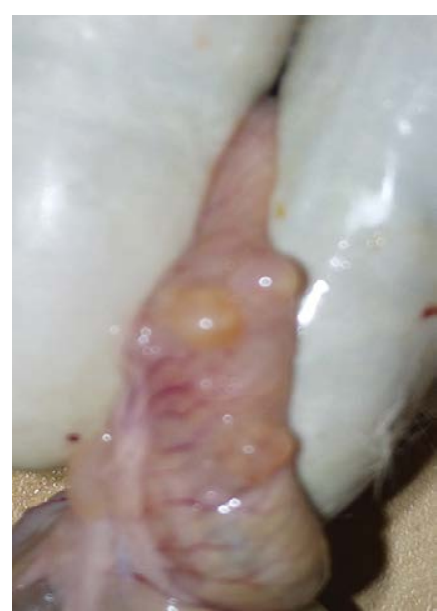

Figure 1: A Pathology condition after indomethacin induced ulcer rats with ulcer rate of $0-3 \mathrm{~mm}$.

\section{Determination of ulcer lesion}

The drug Indomethacin was administered intragastrically via the aid of an orogastric cannula. Four hours later, the rats were sacrificed using chloroform anaesthesia; the stomach was removed and opened along the greater curvature. The tissue was fix with $10 \%$ formaldehyde in saline, microscopic examination was carried out and scored the presence of lesion using the method of Nwafor et al. [11]. Ulcer lesion and weight of the rats were calculated.

\section{Histopathological examination}

The stomach histopathology of all the animals were fixed in $10 \%$ buffered formalin in labelled bottles and processed routinely for histology examination. The tissue embedded in paraffin wax were sectioned in $5 \mu \mathrm{m}$ thick, stained with Haematoxylin and eosin, mounted on glass slides and then examined under 10x microscope.

Severity of gastric ulcer was assessed according to the method by Isaac et al. where the result of the examination was divided into four parameters which are desquamation of surface epithelium (0-3) haemorrhage, focal necrosis and mucosal congestion (0-3), glandular cells degeneration (0-3) and inflammatory cell infiltration (0-3) with a maximum total score of 12 for the most severe condition [7].

Wound healing process was categorized into three categories: No granulation tissue (score 0 ), thin granulation tissue (score 1), mild granulation tissue (Score 2) and thick granulation tissue (score 3) [10].

The Ulcer Area (UA) was calculated. The percentage (\%) of protection $(\mathrm{P} \%)$ availed to the animals through the various treatments were calculated using the formula: 


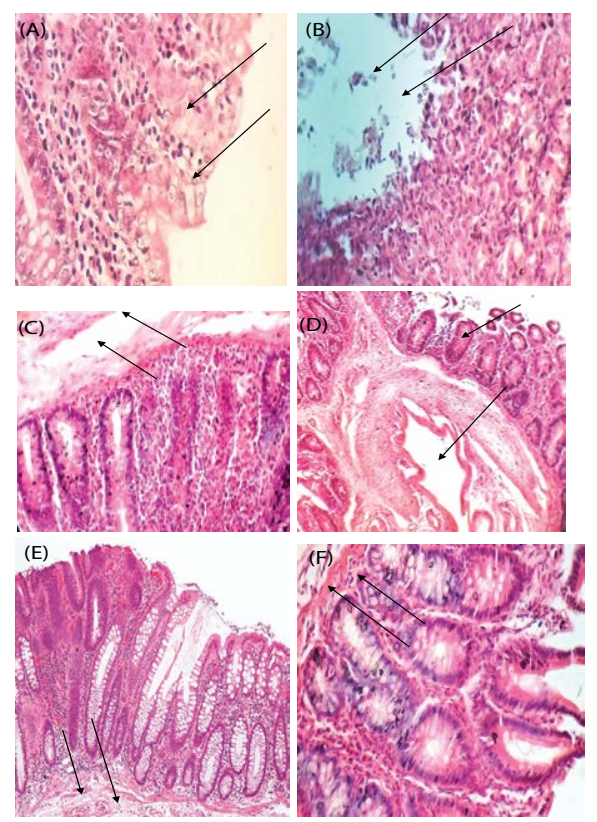

Figure 2: Histopathology examination; A: Healthy animals, B: Untreated animals, C-E: Treatment group with Barringtonia asiatica hexane extracts. F: Treatment Group with positive control group omeprazole. Magnification 40x

$$
\mathrm{P} \%=\frac{(\mathrm{UA} \text { ulcer control }-\mathrm{UA} \text { treatment })}{\text { UA ulcer control }} \times 100
$$

Histopathology data showed that under normal condition (i.e., the healthy animals), rats did not develop any ulcer. The most severe gastric ulcers were found in the untreated animals.

\section{Statistical Analysis}

Data are reported as Mean \pm SD and were analysed statistically using one-way ANOVA followed by student t-test and value of $p<0.05$ were considered significant

\section{Results and Discussion}

The ulcer producing study was performed prior to the mean study of Barringtonia asiatica hexane extract on indomethacin induced ulceration. The purpose of before and after study was to determine whether indomethacin could induce gastric ulcer on the mucous layer. Pathology and histopathology examination showed that the treatment successfully induced gastric ulcer (Table 1 and Figure 1). From the histopathology examination, it was apparent that oedema and haemorrhage with a lot of neutrophils infiltration were found in all groups of the ulcer producing study. Neutrophils were found in the serosa area and spreading to the mucosa of gastric. According to these results, contact with indomethacin was able to induce the ulcer formation successfully with outer layer perforation (Figure 1). Therefore, this method was valid for further study ulcerations.

Thus, to investigating the effect of hexane extract of Barringtonia asiatica on gastric ulcers were performed. In the study it was noticed that the biggest ulceration was seen in untreated animals, as compared to treatment and positive control groups.

All groups except the healthy animals developed ulceration, with the untreated animals forming the most severe ulceration with an area that reached 44-54 $\mathrm{mm}^{2}$ and approximately $2-3 \mathrm{~mm}$ depth. The other treatment groups and positive control showed less severe ulceration upon treatment with $100 \mathrm{mg} / \mathrm{kg} / \mathrm{bwt}, 200 \mathrm{mg} / \mathrm{kg} / \mathrm{bwt}, 300 \mathrm{mg} / \mathrm{kg} / \mathrm{bwt}$, $400 \mathrm{mg} / \mathrm{kg} / \mathrm{bwt}$, and $500 \mathrm{mg} / \mathrm{kg} / \mathrm{bwt}$ of the extracts and omeprazole protection percentage rate of $92.80 \%, 13.94 \%, 33.46 \%, 51.87 \%, 64.34 \%$ and $86.54 \%$ respectively when compared to the untreated animals.

Histopathology examination showed the presence of oedema and haemorrhage in the untreated animals. Macrophages mixed with neutrophils were also found in the cytoplasm from the serosa to submucosa area in dark brown colour. Details of mucus formation and the severity of gastric ulcer were determined through histopathology examination as shown in Figures 2A-2F.

Histopathology data showed that under normal condition the healthy animals did not develop any ulcer. The most severe gastric ulcers were found in the untreated animals. Treatment groups of hexane extract at dose of $100 \mathrm{mg} / \mathrm{kg} / \mathrm{bwt}, 200 \mathrm{mg} / \mathrm{kg} / \mathrm{bwt}, 300 \mathrm{mg} / \mathrm{kg} /$ bwt, $400 \mathrm{mg} / \mathrm{kg} / \mathrm{bwt}$ and $500 \mathrm{mg} / \mathrm{kg} / \mathrm{bwt}$ and omeprazole developed only mild to moderate gastric ulcers with clarity in some area after 21days treatment. Small or absence of ulcer were found in hexane extract at dose of $300 \mathrm{mg} / \mathrm{kg} / \mathrm{bwt}, 400 \mathrm{mg} / \mathrm{kg} / \mathrm{bwt}$, and $500 \mathrm{mg} / \mathrm{kg} / \mathrm{bwt}$ group) as shown in (Figures $2 \mathrm{E}$ and $2 \mathrm{~F}$ ).

However, previous study by Isaac et al. has documented that several evidence showing indomethacin-induced gastric ulcers becomes chronic within a very shortest possible time and heals completely within 21days without perforation or penetration [7]. The ulcer induced by indomethacin is assumed to be similar to that of chronic human ulcer with regards to its location, severity and chronicity as well as with regard to the healing process [11]. There was no significant difference in haematological value among groups in the full study, indicating that the hexane extract did not affect the haematology profile of the induced and non-induced albino rat (Tables 2-4).

The treatment of hexane extract of Barringtonia asiatica at doses of 100, 200, 300, 400 and $500 \mathrm{mg} / \mathrm{kg} / \mathrm{bwt}$ and Omeprazole reduced the rate of ulceration up to $13.94 \%, 33.46 \%, 51.87 \%, 64.34 \%$ and $86.54 \%$ respectively, thus, one will say the extract at $500 \mathrm{mg} / \mathrm{kg} / \mathrm{bwt}$ ameliorates the effect of gastric ulcer with about $86.54 \%$ when compared with the control $92.8 \%$. 
Citation: Umaru IJ, Umaru HA (2018) The Evaluation of Barringtonia asiatica on Indomethacin Induced Ulceration on Albino Rats. J Mol Genet Med 12: 365 doi:10.4172/1747-0862.1000365

Page 5 of 5

from that of the untreated animals. The severity of the ulcer was improved in all treated groups with increase in concentration. The severity scoring for gastric ulcer which was determined by histopathology examination was significant as a result of the mechanism of reaction of some of this bioactive present such as terpene, flavonoid and alkaloid present in the plant Barringtonia asiatica.

The reduction of ulcer area and alleviation of ulcer severity based on the histopathology analyses indicated that hexane extract treatments, either at the dose of $100 \mathrm{mg} / \mathrm{kg} / \mathrm{bwt}, 200,300,400$, and $500 \mathrm{mg} / \mathrm{kg} / \mathrm{bwt}$ on the albino rats, were comparable to that of omeprazole. This may have occurred due to the dual mechanisms of action of hexane extract which extract only the polar bioactive of the Barringtonia asiatica. Extensive studies were carried out to assess the pharmaceutical potential of Barringtonia asiatica. Several studies have shown its potential effect as antibacterial agent [6]. The bioactive component of the extracts characterization is on-going in University Malaysia natural product laboratory

\section{Conclusion}

This study clearly demonstrated that oral administration of the crude extracts of Barringtonia asiatica hexane extract at dose of 100 $\mathrm{mg} / \mathrm{kg} / \mathrm{bwt}, 200 \mathrm{mg} / \mathrm{kg} / \mathrm{bwt}, 300 \mathrm{mg} / \mathrm{kg} / \mathrm{bwt}, 400 \mathrm{mg} / \mathrm{kg} / \mathrm{bwt}$ and 500 $\mathrm{mg} / \mathrm{kg} / \mathrm{bwt}$ were effective for gastric ulcer treatment as measured by the reduction of ulcer size. It is also effective in alleviating ulcer severity as seen from the histopathology result. There was no significant difference in haematological value among groups in the full study, indicating that the hexane extract did not affect the haematology profile of the induced and non-induced albino rat. Thus, demonstrated curative effect on indomethacin-induced gastric ulcer.

\section{Acknowledgments}

The authors would like to thank the staff of natural product Lab Unimas for their contribution and support in one way or the other and the Animal Ethic Committee for granting approval for this research.

\section{Authors Contributions}

Isaac John Umaru and Hauwa A. Umaru were both responsible for the design of this study, execution of the experimentation and analytical evaluation of the study.

\section{Conflict of Interest}

The authors declare no conflict of interest.

\section{References}

1. Tripathi KD (2013) Essentials of medical pharmacology. (6th edn). Jaypee Brothers, New Delhi, India.

2. Berardi RR, Welage S (2005) Peptic ulcer disease. In: Pharmacotherapy: A pathophysiologic approach. (6th edn). McGraw-Hill, USA.

3. Suerbaum S, Michetti S (2002) Helicobacter pylori infection. N Engl J Med 347 1175-1186.

4. Bae DK, Park D, Lee SH, Yang G, Kim YYH (2011) Different antiulcer activities of pantoprazole in stress, alcohol and pylorus ligation-induced ulcer models. Lab Anim Res 27: 47-52.

5. Papich MG (2016) Saunders handbook of veterinary drugs: Small and large animal. (1st edn) Elsevier Health Sci, New York, USA.

6. Umaru IJ, Badruddin FA, Assim ZB, Umaru HA, Thagriki D (2018a) Antibacteria and cytotoxicity studies of Barringtonia asiatica. Anatomy Physiol Biochem Int J 5: $1-4$.

7. Umaru IJ, Badruddin FA, Assim ZB (2018b) Effect of Leptadenia hastata hexane leaf extracts against haematological, biochemical and indomethacin induced ulcer in rats. European J Pharma Med Res 5: 35-41.

8. Gunal O, Oktar BK, Ozcinar E, Tansuker D, Arbak S (2002) Healing-promoting effect of bombesin treatment on chronic gastric ulcer in rats. Reg Peptides 106: 81-88.

9. Umaru IJ, Ahmed FB, Olawale OO, Umaru HA (2018c) Phytochemica evaluation and antioxidant properties of three medicinal plants extracts. Med Analy Chem Int J 2: 1-8.

10. Umaru IJ, Umaru HA (2018d) Antidiabetic potentials of leaves, stem-bark and roots extract of Leptadenia hastata in albino rats. J Chem Sci 1: 1-5.

11. Nwafor PA, Effraim KD, Jacks TW (2012) Gastroprotective effects of aqueous extracts of Khaya senegalenisis bark on indomethacin induced ulceration in rats. West African J Pharmacol Drug Res 12: 46-50. 